\title{
A FUNÇÃO SOCIAL DO DIREITO AUTORAL E O ACESSO AO CONHECIMENTO
}

\section{SOCIAL FUNCTION OF COPYRIGHT AND ACCESS TO KNOWLEDGE}

\author{
Alexandre Azis Pereira Filho \\ alexandrefilho.opo@hotmail.com
}

OSEIAS AMARAL

Atualmente é Mestre em Ciência Política pela Universidade Federal do Rio Grande do Sul. Especialista em Direito Tributário pelo IBET. Professor e Coordenador de Extensão do curso de Direito do Centro Universitário Luterano de Ji-Paraná. Membro do Conselho Consultivo da Revista Jus Societas. Membro do Comitê de Ética em Pesquisa do CEULJI. Professor Líder do Grupo de Pesquisa em Direito Tributário do Curso de Direito do CEULJI. Advogado.

osieas@ulbra.br

Naila Fernanda Sbsczk Pereira Meneguetti Possui graduação em Sistema de Informação pelo Centro Universitario Luterano de Ji-paraná (2008). Pós graduada em Didática e Metodologia do Ensino Superior (2009). Mestranda em Administração pela Universidade Federal de Rondônia - UNIR. naila_sbsczk@hotmail.com

\begin{abstract}
RESUMO
0 presente estudo aborda o tema da função social do direito autoral e o acesso ao conhecimento em face do caráter individualista dos direito autorais. Discute inicialmente o direito de propriedade a fim de apresentar o conceito de função social da propriedade. Analisa historicamente a evolução do direito de propriedade e o surgimento da ideia de função social. Busca enquadrar o direito autoral como um ramo do direito de propriedade, especificamente, a propriedade intelectual. Apresenta e discute sucintamente a Lei $\mathrm{n}^{\circ}$ 9.610/98, diferenciando os direitos patrimoniais dos direitos morais do autor e analisa o sistema criado pela Lei dos Direitos Autorais confrontando-o com os direitos constitucionais de acesso à educação, à cultura, à informação e ao conhecimento. Conclui que o princípio da função social pode ser uma resposta para a necessidade de ajuste entre o sistema de proteção ao autor, criado pela Lei $n^{\circ} 9.610 / 98$ e os direitos constitucionais relacionados ao acesso ao conhecimento.
\end{abstract}

Palavras-chave: ACESSO AO CONHECIMENTO; DIREITO AUTORAL; FUNÇÃO SOCIAL.

\begin{abstract}
The present monograph approach to the social function of copyright and access to knowledge in face of the individualistic aspect of copyright. First discusses the right of property in order to the present concept of social function. Analyzes historical evolution of property rights and the emergence of the idea of social function. Search circumscribe the copyright as a branch of property Law specifically intellectual property. It presents and discusses briefly the Law $n^{\circ} 9.610 / 98$, differing economic rights of the author's moral rights and it analyzes the system established by the Copyright Act confronting it with the Constitutional rights of access to education, culture, information and knowledge. We conclude that the principle of social function may be a response to the need for adjustment between the copyright protection system created by Law $n^{\circ} 9.610 / 98$ and the constitutional rights related to access to knowledge.
\end{abstract}

Keywords: ACCESS TO KNOWLEDGE; COPYRIGHT; SOCIAL FUNCTION. 


\section{SUMÁRIO}

INTRODUÇAO; 1 DIREITO DE PROPRIEDADE; 1.1 Direito de Propriedade no ordenamento jurídico brasileiro; 1.2 Constituição da República Federativa do Brasil de 1988; 1.3 A Função Social do Direito de Propriedade; 2 O DIREITO DO AUTOR ENQUANTO DIREITO DE PROPRIEDADE; 2.1 A lei 9.610/98 como instrumento de proteção do autor; 30 ACESSO À EDUCAÇÃO, À CULTURA, À INFORMAÇÃO E AO CONHECIMENTO; 3.10 conflito entre o Direito Autoral e o Acesso ao Conhecimento; 3.2 A Nova lei de Direito Autoral como Mecanismo de Acesso à Educação, à cultura, à informação e ao Conhecimento; 3.3 A Função Social do Direito de Autor; CONCLUSÃO; REFERÊNCIAS.

\section{INTRODUÇÃO}

Historicamente, o direito autoral foi criado para garantir ao autor o direito de exploração econômica de sua obra, a liberdade de expressão e do exercício do direito individual de propriedade. É um direito constitucional e personalíssimo, o pressuposto desse direito é a originalidade e o caráter de ser uma única criação. Essa proteção tem a finalidade para que nenhuma pessoa reproduza sua obra, sem seu consentimento.

A Carta Magna assegura o direito de propriedade no artigo $5^{\circ}$ XXII (BRASIL, 1988) elencando-o como um direito fundamental no ordenamento jurídico brasileiro. Desta forma o proprietário tem amplo poder sobre que lhe pertence. Nessa concepção o direito de propriedade é o mais amplo direito do cidadão sobre determinada coisa.

O direito ao acesso à informação e ao conhecimento possibilitou um grande avanço no processo de modernização do país e do mundo, a internet propicia a globalização da informação com uma rapidez jamais vista. Com o decorrer do tempo a tecnologia digital possibilitou uma importante ferramenta de comunicação, como processo de criação de obras digitais, mas o direito do autor muitas vezes não é respeitado, a lei de direitos autorais é antiga e precisa urgentemente ser reformada, no entanto, acabou ficando no tempo não acompanhando a modernização. Na atualidade há uma acessibilidade enorme aos meios de comunicação. 0 ordenamento jurídico, ainda não encontrou uma forma para dirimir esse conflito, entre o direito individual, o qual seria o criador da obra ou direito coletivo, o interesse do público que deseja fruir e utilizar as obras digitalizadas. Havendo, portanto, uma colisão de princípios. Todavia o direito de propriedade do autor encontra-se na internet sem nenhum controle do estado, sendo que o mesmo não consegue fiscalizar tamanha invasão ao direito autoral. Portanto, o presente estudo tem por objetivo analisar o direito autoral no confronto em que ele se coloca com os direitos constitucionais à educação, à cultura, à informação e ao conhecimento, propondo a 
noção de função social do direito autoral como instrumento de conciliação dos interesses contraditórios oriundos desses direitos.

Como base teórica foi utilizado uma pesquisa através de livros e artigos, onde foi adotado como procedimento metodológico para este estudo uma análise qualitativa em torno do referencial teórico construído para a compreensão e discussão do tema abordado.

O texto está estruturado em três partes, o primeiro capítulo se propõe a analisar o direito de propriedade desde suas origens até a incorporação da noção de que a propriedade necessita cumprir uma função social. O segundo capítulo trata especificamente sobre o direito de autor, analisando sucintamente a legislação que o regula (Lei $\mathrm{n}^{\circ} \mathrm{9.610/98}$ ), buscando situa-lo como um direito especial, sui generis, com facetas patrimoniais e morais, derivado da propriedade intelectual. O terceiro capítulo analisará a importância do acesso à educação, à cultura, à informação e ao conhecimento para a sociedade, direitos estes garantidos pela Constituição Federal de 1988 nos artigos $5^{\circ}$ XIV, 6, 205 e 215.

\section{DIREITO DE PROPRIEDADE}

Segundo Venosa (2007), é difícil saber precisamente em que momento surge, na sociedade romana, a primeira forma de propriedade, pois não é muito clara nas fontes a forma de propriedade comum na primitiva Roma. No primeiro período do Direito Romano, o indivíduo recebia uma porção de terra que devia cultivar, mas, uma vez terminada a colheita, a terra voltava a ser coletiva. Paulatinamente fixou-se o costume de conceder sempre a mesma porção de terra às mesmas pessoas ano após ano. Ali, o pater familias instalava-se, construía sua moradia e vivia com sua família e escravos. Nesse sentido, arraigou-se no espírito romano a propriedade individual e perpétua. A lei das XII Tábuas, de 417 a. C., a primeira lei romana, projeta a noção jurídica do direito de usar, gozar e dispor da coisa. O domínio sobre a terra era considerado de forma absoluta (VENOSA, 2007, p. 142 apud PETIT, 1970, p. 242).

O sistema jurídico dos romanos fixou a concepção de uma propriedade rigorosamente individualista e exclusiva, em que o proprietário era o único dono de seu bem. Esta ideia acompanhou todo período romano. Todavia, apesar de existirem vários conceitos esparsos, os romanos não definiram o direito de propriedade (VARELLA, 1996, p. 22).

As mudanças ocorridas na concepção da propriedade iniciaram-se com a queda do império romano. Na Idade Média, a propriedade perde o caráter unitário e exclusivista. Com as 
ISSN 1981-3694

(DOI): $10.5902 / 1981369410564$

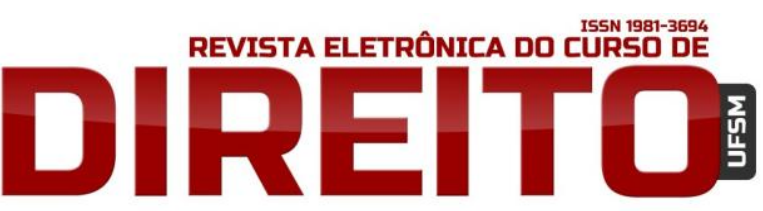

A FUNÇÃO SOCIAL DO DIREITO AUTORAL E O ACESSO AO CONHECIMENTO

Alexandre Azis Pereira Filho, Oseias Amaral, Naila Fernanda SbsczK PEREIRA MENEGUETTI

diferentes culturas bárbaras, modificam-se os conceitos jurídicos. 0 território passa a ser sinônimo de poder e a ideia de propriedade está ligada à de soberania nacional, com os Vassalos servindo ao senhor (VENOSA, 2007, p. 143 apud CÂMARA, 1981, p. 79).

A insegurança e o receio sugeriram a ideia de transferência da terra aos poderosos, com juramento de submissão e vassalagem, em troca de proteção à sua fruição e, na medida em que a classe dominada se estendia, crescia o conceito de poder político ligado à propriedade imobiliária (PEREIRA, 2004, p. 82). Assim, a propriedade foi revestida de aparência política. Unia-se a ideia de propriedade à de soberania territorial. O poder concentrava-se na mão dos monarcas, o estado era o rei e estava vinculado ao Papa. Existia neste tempo uma superposição de domínios de densidades diferentes que se mantinham paralelamente, em que o domínio direto era do senhor feudal e o útil dos vassalos (VARELLA, 1996, p. 22).

Esta visão que unia a propriedade ao poder absoluto do rei sofreu uma tímida limitação por meio da Carta Magna 1215 (USP, 2012), que dispunha que o homem não podia ser privado de seus bens antes do julgamento. Todavia foi só a partir do século XVIII, com a escola do direito natural que surgiu a ideia de regular por meio de lei o direito de propriedade. Esta escola, fruto do iluminismo, teve como resultado dois eventos contraditórios.

O primeiro foi o resultado de uma nova compreensão da propriedade manifestado na Revolução Francesa, que pretendeu democratizar a propriedade e, em busca de interesses mais sociais para propriedade, aboliu privilégios e cancelou direitos perpétuos. Desprezando a coisa móvel, concentrou sua atenção na propriedade imobiliária. Entretanto com a Declaração dos Direitos do Homem e do Cidadão de 1789, produto jurídico da Revolução, houve um estreito vínculo entre a noção de pessoas e de propriedade, com esteira na doutrina liberal, que levou o direito de propriedade a ser erigido em um dos direitos fundamentais do homem, ao lado da liberdade e da segurança. Tais direitos humanos, a partir da Constituição dos Estados Unidos da América, foram progressivamente adotados pelas leis fundamentais de diversos países do mundo Ocidental, num processo difundido de positivação e constitucionalização dos direitos individuais (MOTTA, 1997, p. 39).

Na Declaração dos Direitos do Homem e do Cidadão de 1789 (MPF, 2012) a propriedade foi erigida em direito inviolável e sagrado para os homens.

De outro lado, o Code Napoléo - que serviria de modelo a todo movimento codificador no século XIX, foi uma reação às tendências manifestadas na Revolução. Tamanho prestígio deu este código ao instituto, que com razão recebeu o apelido de “código da propriedade”, fazendo ressaltar acima de tudo o prestígio do imóvel, fonte de riqueza e símbolo de estabilidade 
ISSN 1981-3694

(DOI): $10.5902 / 1981369410564$

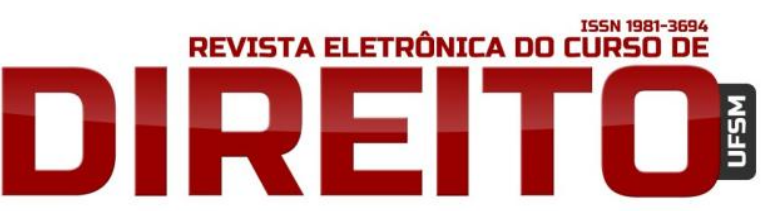

A FUNÇÃO SOCIAL DO DIREITO AUTORAL E O ACESSO AO CONHECIMENTO

Alexandre azis Pereira Filho, Oseias Amaral, Naila Fernanda SbsczK PEREIRA MENEGUETTI

(PEREIRA, p. 83, 2004). O Código de Napoleão, acolhendo a concepção romana, traça a conhecida concepção extremamente individualista do instituto no art. 544: "A propriedade é o direito de gozar e dispor das coisas do modo absoluto, desde que não se faça uso proibido pelas leis ou regulamentos". Como sabido, esse Código repercutiu em todos os ordenamentos que se modelaram no Código Civil Francês, incluindo-se a grande maioria dos códigos latino-americanos (VENOSA, 2007, p. 143). Avançando na história, com o advento da Revolução Industrial, ocorreram inúmeras transformações, o desenvolvimento econômico, a descoberta da máquina, a industrialização, fizeram com que o individualismo exacerbado consagrado na noção clássica de direito de propriedade contribuísse para uma concentração excessiva de riquezas nas mãos de uns proprietários, enquanto outros nada possuíam (VARELLA, 1996, p. 23).

Em face da configuração da sociedade industrial, o direito de propriedade passou a ser visto sob um prisma menos individualista, resgatando, de certo modo, o lado social deste direito. No século XIX, a crítica marxista, já no século XX, a realidade socialista da URSS influenciaram nesse processo. A ideia de estado social expressa na Constituição Mexicana de 1917 e na Constituição Alemã de 1919 traz embutido em si, além do estado liberal, uma nova visão sobre o direito de propriedade. Outro marco jurídico relevante sobre a propriedade surgiu após a segunda Guerra Mundial, por meio da Declaração Universal dos Direitos Humanos (CÔMITE, 2012) artigo 17, porém a mesma não especificou o direito de propriedade que declarava.

\subsection{Direito de Propriedade no ordenamento jurídico brasileiro}

Não havia a ideia de propriedade para os povos primitivos brasileiros, pois ao tempo da descoberta do Brasil, havia domínio comum das coisas úteis, entre os que habitavam a mesma oca, individualizando-se, tão somente, a propriedade de certos móveis, como redes, armas e utensílios de uso próprio. O solo, por sua vez, era pertencente a toda tribo e isso, temporariamente, porque os índios não se fixavam na terra, mudando-se de cinco em cinco anos (Diniz, 2008, p. 105 apud STERBERG, 1930, p. 32).

Em face disso, a ideia de propriedade é regulada juridicamente no Brasil apenas após a chegada dos portugueses. A Constituição de 1824 foi outorgada pelo Imperador D. Pedro I. Nesse período a propriedade foi marcada pelo individualismo. A Constituição Brasileira de 1824 (BRASIL, 1824) regulava a propriedade nos seguintes termos:

Art. 179. XXII. É garantido o Direito de Propriedade em toda a sua plenitude. Se o bem público legalmente verificado exigir o uso, e emprego da Propriedade do 
Cidadão, será elle préviamente indenizado do valor della. A Lei marcará os casos, em que terá logar esta única excepção, e dará as regras para se determinar a indenização.

A Carta Constitucional do Império, no seu artigo 179 elencou a propriedade como um dos direitos fundamentais dos cidadãos brasileiros. Conforme Motta (1997, p. 35), esta Carta corresponde à concepção idealista do modelo jus naturalista, que buscava sua base de fundamentação em uma visão abstrata pela qual os direitos seriam inerentes à própria natureza racional do ser humano. A propriedade, mediante uma noção contratualista é considerada direito natural fundamental e inalienável.

Com a queda do Império em 1889 e com advento da Constituição Republicana de 1891 (BRASIL, 1891), o direito de propriedade foi assim regulado:

Art. 72. § 17 - 0 direito de propriedade mantém-se em toda a sua plenitude, salva a desapropriação por necessidade ou utilidade pública, mediante indenização prévia. As minas pertencem aos proprietários do solo, salvas as limitações que forem estabelecidas por lei a bem da exploração deste ramo de indústria.

Com advento da Constituição Republicana e o ingresso do Brasil no seu segundo período constitucional, com olhar voltado para Constituição dos Estados Unidos da América, rompido o padrão absolutista monárquico, adotou-se a plenitude formal das instituições liberais, baseadas no conceito individualista de liberdade, que perdurou na Constituição Republicana de 1891 durante cerca de quarenta anos (BONAVIDES, 1993, p. 291).

A Constituição de 1891 foi além da primeira Constituição, pois assegurou o direito de propriedade aos brasileiros e garantiu também aos estrangeiros residentes no País. E ainda manteve a propriedade dentro dos direitos e garantias individuais. Nesse contexto Constitucional liberal foi promulgado o Código Civil de 1916, (BRASIL, 1916) que quanto ao direito de propriedade, dispunha:

Art. 524 A lei assegura ao proprietário o direito de usar, gozar e dispor de seus bens e de reavê-los do poder de quem quer que injustamente os possua.

Parágrafo Único. A propriedade literária, científica e artística será regulada conforme as disposições do capítulo VI deste título.

Art. 525 É plena a propriedade, quando todos os seus direitos elementares se acham reunidos no do proprietário; limitada, quando tem ônus real, ou é resolúvel.

Art. 526 A propriedade do sobre e do subsolo abrange a do que the está superior e inferior em toda altura e em toda a profundidade, úteis ao seu exercício, não podendo, todavia, o proprietário impedir trabalhos, que sejam empreendidos a uma altura ou profundidade tais, que não tenha ele interesse em obstá-los.

Em uma redação infeliz, o Código Civil de 1916 instituiu a extensão do direito de propriedade ao espaço aéreo e ao subsolo em toda altura e em toda profundidade úteis ao seu 
exercício, não podendo, todavia, opor-se o proprietário a trabalhos que sejam empreendidos até onde não exista o interesse de impedi-los. Desta maneira conjugou a utilidade e o interesse. Porém essa redação infeliz do artigo 526 do Código Civil de 1916 foi corrigida mais tarde pelo Decreto do Poder Legislativo $n^{\circ} 3.725$ de 1919 (PEREIRA, 2004, p. 291).

O direito de propriedade segundo o Código Civil de 1916 engloba tanto os bens corpóreos e incorpóreos, como os móveis ou imóveis, tendo como objeto, em regra geral todos os bens apropriáveis. Nesse sentido o Código Civil de 1916 colocou a propriedade literária, científica e artística disciplinada entre os direitos de propriedade no seu art. 524, parágrafo único (VENOSA, 2007, p. 155). O Código Civil de 1916 vigorou durante 86 anos, sendo substituído apenas em 2002. Todavia, as diversas alterações constitucionais no período impuseram novos elementos à noção de Direito de propriedade, mesmo sem alterar a letra do Código Civil de 1916.

Com a promulgação da Constituição de 1934 iniciou-se o terceiro período constitucional brasileiro, apresentando uma corrente de princípios que ressaltava o aspecto social dos direitos fundamentais, até então ausentes dos textos constitucionais pátrios. (MOTTA, 1997, p. 2). Nesse sentido, a Constituição de 1934 (BRASIL, 1934) além de manter a propriedade dentre os direitos e garantias individuais, foi à primeira constituição a tratar o direito de propriedade no capítulo da ordem social e econômica, já apresentando as primeiras linhas sobre um condicionamento social para a concepção da propriedade (BELTRÃO, 2012, p. 2). A Constituição Brasileira de 1934 deixa de prever um direito de propriedade completamente individualista, passando a proteger mais os interesses da coletividade, sendo mantido o direito de propriedade, no entanto limitaram-se os direitos do titular sobre sua propriedade.

A Constituição seguinte, de 1937, a Constituição do Estado Novo ou "Constituição Polaca", retirou a proteção dos interesses coletivo e social da propriedade e ainda restringiu os direitos e garantias fundamentais. Houve um retrocesso dos direitos já adquiridos, trazendo consigo um caráter ditatorial e a concentração de poderes na mão do Presidente da República (BRASIL, 1937). Todavia, manteve o direito de propriedade, nos seguintes termos:

Art. 122. § 14- o direito de propriedade, salvo a desapropriação por necessidade ou utilidade pública, mediante indenização prévia. 0 seu conteúdo e os seus limites serão os definidos nas leis que the regularem o exercício;

A Constituição Brasileira de 1946 (BRASIL, 1946) derrubou a Constituição do Novo Estado pondo fim à restrição aos direitos e garantias fundamentais. Como novidade relativa ao direito de propriedade, introduziu a cláusula da função social da propriedade, por meio da qual o interesse social prevalecia sobre o interesse particular, nos seguintes termos: 
Art. 141. § 16 - É garantido o direito de propriedade, salvo o caso de desapropriação por necessidade ou utilidade pública, ou por interesse social, mediante prévia e justa indenização em dinheiro. Em caso de perigo iminente, como guerra ou comoção intestina, as autoridades competentes poderão usar da propriedade particular, se assim o exigir o bem público, ficando, todavia, assegurado o direito a indenização ulterior.

O texto Constitucional de 1946, além de recapitular os direitos e as garantias elencados pela Segunda Constituição, manteve o direito de propriedade dentro dos direitos fundamentais, e ainda inseriu em um novo título dedicado à ordem econômica e social, contemplou a função social da propriedade, que passou de uma concepção liberal para uma subordinação do proprietário para que atendesse o fim social da propriedade. Embora garantida como direito fundamental, à propriedade privada foram impostas limitações, subordinando o exercício da propriedade ao bem estar da coletividade (MOTTA, 1997, p. 47).

O golpe militar de 1964 levou à promulgação da Constituição Brasileira de 1967 que adotava um regime autoritário (BRASIL, 1967). Apesar de restringir e reduzir muitos direitos, o regime militar garantiu o direito de propriedade e ainda, com relação à ordem econômica, orientou-a com a finalidade de realizar a justiça social, por meio do principio da função social da propriedade (PEREIRA, 2004, p. 103-104). Em 1969 não houve uma Constituição, mas sim a reforma da Constituição Federal de 1967, que vigorou até a promulgação da Constituição Brasileira de 1988. A Emenda $n^{\circ} 1$ de 69 (BRASIL, 1969) garantiu a inviolabilidade do direito de propriedade, mas estabeleceu restrições e limitações às pessoas naturais e jurídicas, para defesa da integridade do território, a segurança do estado e a justa distribuição da propriedade.

Como pode ser visto o ordenamento jurídico brasileiro acompanhou, sobretudo por meio de suas Constituições, a evolução acerca do direito de propriedade, muitas vezes de forma autoritária, mas não deixou em momento algum de retirar esse direito tão fundamental aos cidadãos que é o direito de propriedade. Entretanto desde a Constituição do Império em 1824 até a Constituição Federal de 1988, o país passou por diversas mudanças políticas e sociais, uma das mudanças que foi relevante para sociedade foi à proteção do interesse coletivo em face do individual, como por exemplo, a função social da propriedade introduzida no texto Constitucional de 1946. Neste contexto passaremos a analisar com detalhes a Constituição Federal de 1988 e o Código Civil de 2002. 


\subsection{Constituição da República Federativa do Brasil de 1988}

A Constituição Federal de 1988 traz referências expressa ao direito de propriedade no artigo $5^{\circ}$, inciso XXII, elencando-o como um direito fundamental dos cidadãos, desta forma as pessoas podem desfrutar de suas propriedades da forma como queiram, mas desde que atendam aos princípios da função social da propriedade. Mendes (2008) afirma que o direito de propriedade, ao contrário do direito à vida ou à liberdade de ir e vir, por exemplo, não pertence à natureza do ser humano, tendo na ordem jurídica a instituição direta e expressa do seu âmbito de proteção. É a Constituição Federal que dá a tal direito o status de garantia institucional, sendo uma norma auto executável, mas cujo conteúdo está definido em lei.

Observa-se que no decorrer das décadas o direito de propriedade sofreu diversas alterações, antes esse direito era visto como um direito absoluto, perpétuo e exclusivo do seu titular, hoje a propriedade é vista com outros olhos a do dever social, prevalecendo o interesse da coletividade. $O$ direito de propriedade foi concebido como uma forma de proteção e garantia constitucional, do titular da coisa em face dos abusos do Estado.

O direito de propriedade, em consonância com a Constituição Federal de 1988, deve ser exercido tendo em mira a finalidade econômica e social da coisa, e, caso o poder público necessite da propriedade por interesse de utilidade pública ou interesse social, a propriedade será desapropriada com justa indenização. Observa-se que na atualidade a propriedade está voltada mais para o direito público do que para o direito privado, pois prevalece o interesse da coletividade e o bem estar social. Isto posto será analisado o direito de propriedade no Código Civil de 2002. A propriedade é considerada o direito real de maior conteúdo e o mais amplo. Todos os outros têm abrangência mais restrita. Consiste em um direito acerca do qual as pessoas têm a faculdade de usar, gozar, dispor, bem assim de reivindicar a coisa de quem injustamente a possua ou detenha (MATHIAS, 2007, p. 42).

$\mathrm{O}$ direito de propriedade, devido à sua oponibilidade erga omnes, é o mais completo dos direitos reais. Dessa forma o titular desse direito tem a faculdade de desfrutar do seu bem como queira, dentro dos limites estabelecidos na lei, em razão do interesse público em face do bem estar da sociedade. Sendo assim o primeiro elemento constitutivo da propriedade é o direito de usar, que consiste na faculdade do titular servir-se da coisa e de utilizá-la da maneira que entender conveniente, podendo excluir terceiros de igual uso. 0 segundo é o direito de gozar ou usufruir, que compreende o poder de perceber os frutos naturais e os civis da coisa e de aproveitar economicamente os seus produtos. O terceiro é o direito de dispor da coisa, de 
transferi-la, de aliená-la a outrem a qualquer título. Envolve a faculdade de consumir o bem, de dividi-lo ou de gravá-lo. Não significa, porém, prerrogativa de abusar da coisa, destruindo-a gratuitamente, pois a própria Constituição Federal prescreve que o uso da propriedade deve ser condicionado ao bem-estar social. O quarto elemento é o direito de reaver a coisa, de reivindicá-la das mãos de quem injustamente a possua ou detenha. Envolve a proteção específica da propriedade, que se perfaz pela ação reivindicatória (GONÇALVES, 2007, p. 110).

Uma das características marcante do direito de propriedade é o de ser exclusiva. A plenitude da propriedade está contemplada no direito que tem o dono do bem de usar, fruir e dispor. A exclusividade manifesta-se na oponibilidade erga omnes, por meio da qual o proprietário exclui ou impede a ingerência de terceiros. (MATHIAS, 2007, p. 43). 0 direito autoral é também um dos direitos fundamentais, que consagra a Constituição Federal de 1988 no seu artigo $5^{\circ}$, que prescreve:

XXVII - Aos autores pertence o direito exclusivo de utilização, publicação ou
reprodução de suas obras, transmissível aos herdeiros pelo tempo que a lei fixar;
XXVIII- são assegurados, nos termos da lei: a) a proteção as participação
individuais em obras coletivas e à reprodução da imagem e voz humanas,
inclusive nas atividades desportivas; b) o direito de fiscalização do
aproveitamento econômico das obras que criarem ou de que participarem aos
criadores, aos intérpretes e às respectivas representaçães sindicais e
associativas, sendo assim a lei dos direito autorais, veda a violação da
propriedade intelectual.

Cumpre chamar atenção para o fato, não apontado na doutrina, de que a constituição regula o direito autoral logo abaixo do direito de propriedade, admitindo-o, implicitamente como um sub-direito do direito de propriedade. Esta relação será melhor explorada adiante. Necessário sublinhar também o assento constitucional que possuem os direitos à Educação, à Informação e a Cultura, nos artigos $5^{\circ}$, XIV, 6, 205, 215. O conflito que estes direitos impõem que, de resto, também se assemelha ao conflito entre o direito de propriedade em geral com os princípios da diminuição da desigualdade social, erradicação da pobreza e construção de uma sociedade justa e solidária (art. $3^{\circ}$ da Constituição Federal).

\subsection{A Função Social do Direito de Propriedade}

O direito de propriedade a partir do século XX sofreu inúmeras mudanças sociais, pois foi incorporada a propriedade a ideia de função social, partindo de um pressuposto que o proprietário deveria utilizar sua propriedade em benefício da coletividade, e não mais atendendo somente sua satisfação exclusiva (FILHO, 2012, p. 12). 
ISSN 1981-3694

(DOI): $10.5902 / 1981369410564$

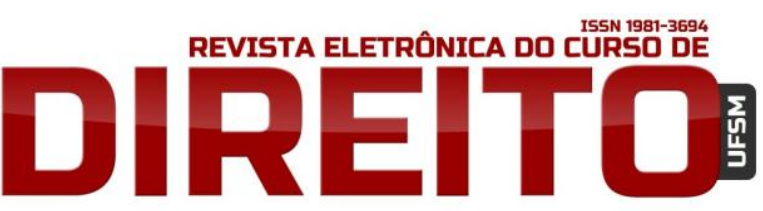

A FUNÇÃO SOCIAL DO DIREITO AUTORAL E O ACESSO AO CONHECIMENTO

Alexandre Azis Pereira Filho, Oseias Amaral, Naila Fernanda SbsczK PEREIRA MENEGUETTI

Segundo Varella (1996, p. 119), a ideia de função social da propriedade surge na encíclica Rerum Novarum, do Papa Leão XIII, por volta de 1891. Essa encíclica pregava o caráter natural do direito de propriedade, sem negar-lhe, todavia, a necessidade do cumprimento de sua função social. A ideia causou grande repercussão e aceitação, dando impulso a inúmeras reformas e influenciando nas diretrizes dos diversos ordenamentos jurídicos ocidentais posteriores. No entanto a função social da propriedade se originou com as Constituições do México de 1917 e da Alemanha de 1919 (Constituição de Weimar). A primeira Constituição elencou no seu artigo 27, que "A Nação terá, a todo tempo, o direito de impor à propriedade privada as determinações ditadas pelo interesse público (...)”, enquanto a segunda Constituição afirmou, no seu artigo 153 que "A propriedade obriga e o seu uso e exercício devem ao mesmo tempo representar uma função no interesse social” (FILHO, 2012, p. 6).

A função social é um limite encontrado pelo legislador para descrever a propriedade, em obediência ao princípio constitucional da supremacia do interesse público sobre o interesse privado, tendo como fundamento o artigo $5^{\circ}$ inciso XXIV da CF/88. Nesse sentido, a doutrina sustenta que sempre que houver um conflito entre o interesse público com um interesse particular, deve prevalecer o princípio da supremacia do interesse público, porque tal princípio representa a vontade da coletividade, que não pode ser submetida à vontade de um indivíduo apenas (VARELLA, 1996, p. 121). Contudo o uso da propriedade deve ser de forma efetiva e socialmente adequada. Pois busca equilibrar o direito de propriedade como uma satisfação de interesses particulares, e sua função social, visa atender ao interesse público e ao cumprimento de deveres para com a sociedade (DINIZ, 2007, p. 108). Vislumbra-se uma diferença de posição, pois para Varella o interesse público deve sempre prevalecer sobre o interesse individual, princípio da Supremacia do interesse público, sendo radical em suas afirmações e não descreve qual é o limite. Diniz é um pouco mais cautelosa em suas afirmações, pois entende que há uma necessidade de um equilíbrio do interesse público em face do interesse particular.

A função social da propriedade foi introduzida no ordenamento jurídico brasileiro por meio da Constituição Federal de 1946, trazendo consigo o conceito de propriedade completamente diferente daquele até então vigente. Conferiu aos cidadãos o direito de propriedade, mas desde que fosse voltado ao interesse social e ao bem estar da coletividade. Conforme Filho (2012, p. 6) a função social, cumpre o papel de elemento inibidor e repressor das distorções jurídicas originárias da degenerada e ilegítima utilização da propriedade. A função social de propriedade objetiva manter ou repor a propriedade na sua destinação normal, de forma que a mesma seja benéfica e útil a todos, e não apenas ao proprietário. 
ISSN 1981-3694

(DOI): $10.5902 / 1981369410564$

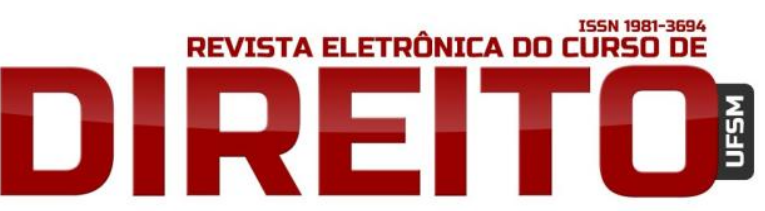

A FUNÇÃO SOCIAL DO DIREITO AUTORAL E O ACESSO AO CONHECIMENTO

Alexandre Azis Pereira Filho, Oseias Amaral, Naila Fernanda SbsczK PEREIRA MENEGUETTI

0 artigo 157 da Constituição de 1967 trouxe, pela primeira vez, de forma expressa, a função social da propriedade em forma de princípio, deixando de vez as características da propriedade exclusiva e absoluta, buscando realizar a justiça social, o que foi mantido pela reforma de 1969. Hodiernamente, após essa evolução histórica do direito de propriedade, o seu próprio conceito resta modificado, em razão da inserção da cláusula da função social, deixando de estar impregnado, como outrora ocorria das características de exclusividade e absolutismo (REIS, 2008, p. 155). Nesse sentido, a Constituição Brasileira de 1988 ao nascer, agrega ao direito de propriedade que reconhece um conjunto de exigências e características, ao referir, por duas vezes, a função social que deve cumprir a propriedade, nos artigos $5^{\circ}$ e 170 , litteris:

Art. $5^{\circ}$. XXIII - a propriedade atenderá a sua função social;

Art. 170. III - função social da propriedade;

A função social da propriedade a vincula não só à produtividade do bem, como também aos reclamos da justiça social, visto que deve exercida em prol da coletividade. Segundo Diniz (2007, p. 107) fácil é perceber que os bens, que constituem objeto do direito de propriedade, devem ter utilização voltada à sua destinação socioeconômica. 0 princípio da função social da propriedade está atrelado, portanto, ao exercício do seu titular e não ao direito de propriedade. Portanto a propriedade esta voltada para o bem estar da coletividade, e não mais para os interesses do proprietário. No entanto cabe ao legislador ordinário equacionar o justo equilíbrio entre o individual e o social. Devendo o poder judiciário quando provocado avaliar e traduzir esse equilíbrio e aparar os excessos no caso concreto sempre que necessário (VENOSA, 2007, p. 149). Assim, a propriedade individual vigente no ordenamento jurídico brasileiro não conserva seu conteúdo idêntico ao de suas origens históricas. Segundo Pereira (2004, p. 84), é certo que se reconhece o poder sobre a coisa; e que o domínio enfeixa os mesmos atributos originários, mas é inegável também que essas faculdades suportam evidentes restrições legais, tão frequentes e severas, que se vislumbra a criação de novas noções tendentes a coibir abusos e tendo em vista impedir que o exercício do direito de propriedade se transforme em instrumento de dominação. Tal tendência ora se diz "humanização" da propriedade.

O Código Civil de 2002 por meio do disposto no art. 1.228 , $\S \S 1^{\circ}$ a $5^{\circ}$, coíbe o uso abusivo da propriedade, que deve ser utilizada para o bem comum da sociedade. Condicionada está à convivência privada ao interesse coletivo, visto que a propriedade necessita cumprir sua função social, logo, seu exercício não mais gira em torno dos interesses individuais do seu titular, e para Diniz (2007, p. 108) os atos que excedem os limites do direito de propriedade estão proibidos, por isso o proprietário, antes de exercer seu direito, deverá verificar a legitimidade do seu 
interesse, evitando qualquer prejuízo a outrem. O direito de propriedade no atual Código Civil mantém sua natureza de direito real, perpétuo e exclusivo, porém não ilimitado, por estar seu exercício condicionado ao pressuposto de que deve ser socialmente útil. Reprimido está, juridicamente, o exercício que não esta em consonância com as suas finalidades econômicas e sociais do direito de propriedade. 0 proprietário deverá conformar o exercício do seu direito ao bem-estar social, sem que isso venha a negar seu domínio. 0 exercício do domínio deve ser instrumento de cooperação social e de consecução de finalidades públicas. Nesse contexto, tanto no âmbito do direito constitucional quanto do direito civil brasileiro existe uma tendência no sentido de limitar as garantias que a lei oferece ao uso do bem, buscando o cumprimento de sua função social. Segundo Varella (1996, p. 120), tem surgido uma tendência, não de abolição da propriedade privada, mas uma crescente determinação de limitar, restringir, ou até mesmo desapropriar a propriedade quando o interesse da coletividade assim exigir e fizer preponderar o interesse público sobre o particular.

Venosa (2007, p. 147) entende que assim como não existe concepção de direito para o homem só, isolado em uma ilha, não existe propriedade, como entidade social e jurídica, que possa ser analisada individualmente. A justa aplicação do direito de propriedade depende do encontro do ponto de equilíbrio entre o interesse coletivo e o interesse individual. Esse equilíbrio nem sempre é alcançado pelas leis, cabendo à jurisprudência responder aos anseios da sociedade em cada momento histórico. Portanto com o estudo da função social da propriedade percebemos que ela surgiu para equilibrar as atividades econômicas e sociais, e reduzir os níveis de injustiças sociais da sociedade e também para sancionar o proprietário com a perda se sua propriedade caso não utilize de modo adequado a atender aos interesses da coletividade.

\section{O DIREITO DO AUTOR ENQUANTO DIREITO DE PROPRIEDADE}

O direito de autor é um direito especial, sui generis, pois da análise do conteúdo do direito de autor, observa-se a coexistência de dois direitos autônomos, sendo estes os de cunho moral, relacionados à proteção da personalidade do criador da obra e outros de cunho patrimonial, referindo-se aos direitos de utilização econômica da obra (BITTAR, 2001, p. 10).

Leite (2005, p. 116) afirma que nas civilizações gregas e romanas, inexistiam os direitos de autor para proteger as diversas manifestações de uma obra, como sua reprodução, 
publicação, representação e execução. Concebia-se na época, que o criador intelectual não devia "descer à condição de comerciante dos produtos de sua inteligência".

A invenção da tipografia e da imprensa, no século XV, por volta de 1401 , revolucionou os direitos autorais, porque os autores passaram a ter suas obras disponíveis de maneira muito mais ampla. Nessa época surgiram os privilégios concedidos a livreiros e editores, verdadeiro monopólio, sem haver ainda a proteção aos direitos autorais (PARANAGUÁ; BRANCO, 2009, p.15).

0 direito de autor tem suas raízes reconhecidas nos privilégios editoriais da Inglaterra, tendo como primeiro ato legal o Copyright Act, de 1709. Segundo Guerreiros Junior (2005, p. 47), o direito do autor, pertencente ao âmbito do Direito Privado, busca a regulação das relações jurídicas decorrentes das manifestações pessoais de criatividade e dons artísticos humanos, que podem ser economicamente utilizados.

Em 1886 representantes de diversos países se reuniram na cidade de Berna, na Suíça, para definir padrões mínimos de proteção dos direitos autorais a serem concedidos aos autores de obra literária, artísticas e científicas. Desta forma, celebrou-se a Convenção de Berna, que desde então serviu de base para a elaboração das diversas legislações nacionais sobre a matéria (PARANAGUÁ; BRANCO, 2009, p.17).

Reis (2008, p. 156) dá noticia de que no Brasil, desde o período colonial, por meio das Ordenações Filipinas de 1603, vigorava uma regulação tendente a reger o direito autoral, todavia, a primeira lei autoral do Brasil (Lei $n^{\circ}$ 496/1898) fazia depender o direito de um registro, que tinha que ser feito dentro de dois anos após a publicação da obra, sob pena de ser abrir mão dele no caso da não efetivação do registro (HAMMES, 2002, p. 23).

O Código Civil de 1916 estabelecia no seu artigo 48, inciso III, os direitos de autor como bens móveis e fixava no artigo 178, parágrafo 10, inciso VII, em cinco anos a prescrição da ação judicial por ofensa a direito de autor, contado esse prazo a partir da contrafação (REIS, 2008).

0 direito autoral foi regulado pela primeira vez de forma completa no Brasil pela Lei $n^{\circ}$ 5.988/73, fundamentada na disposição constitucional da Emenda $\mathrm{n}^{\circ} 1$ de 1969 , que assegurava aos autores de obras literárias, artísticas e científicas o direito exclusivo, sendo esse direito transmissível por herança, pelo tempo que a lei fixasse (PARANAGUÁ; BRANCO, 2009, p.19).

A proteção ao direito de autor em nível constitucional atualmente encontra-se presente no inciso XIV, do artigo $5^{\circ}$ da Constituição Federal, que prevê que ao autor é concedido o “direito exclusivo de utilização, publicação ou reprodução de suas obras”, conferindo-lhe ainda o direito de fiscalização sobre a utilização econômica das obras que criar ou em que participar 
ISSN 1981-3694

(DOI): $10.5902 / 1981369410564$

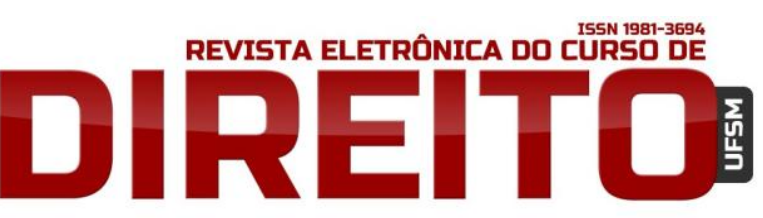

A FUNÇÃO SOCIAL DO DIREITO AUTORAL E O ACESSO AO CONHECIMENTO

Alexandre Azis Pereira Filho, Oseias Amaral, Naila Fernanda SbsczK PEREIRA MENEGUETTI

da criação. Assim, a Constituição Federal de 1988 reconhece ao Direito do Autor o status de Direito Fundamental Individual (PIRES; REIS, 2010, p. 30).

A Lei $n^{\circ} 9.610$ de 1998, atual Lei dos Direitos Autorais, que veio a substituir a Lei $n^{\circ} 5.988$ de 1973, foi elaborada a partir dos princípios estabelecidos pela Convenção de Berna, de 1886 e tem como objetivo a proteção dos bens intelectuais de cunho literário, científico ou artístico (PIRES; TOLLOTTI, 2005, p. 8; BRANCO, 2007, p. 123). Sendo assim a Convenção de Berna, exige de todos os países membros o pleno reconhecimento do direito de autor aos nacionais de qualquer estado signatário da convenção. 0 país signatário pode impor as formalidades que acham importantes aos seus cidadãos, mas não pode impô-las aos outros países signatários. Mesmo assim, deve dar-lhes toda proteção que concedem aos seus nacionais. Em virtude dessas exigências, os Estados Unidos da América do Norte, e muitos outros países, não puderam entrar na Convenção Berna até que adaptassem sua lei a essa solicitação (HAMMES, 2002, p.60).

O direito autoral é um ramo específico da propriedade intelectual. A propriedade intelectual é considerada um conjunto de disciplinas relativamente novas que foram incluídas em diversas áreas do direito com as quais apresentam afinidade (BRANCO, 2007, p. 124). Nesse sentido o Código Civil de 1916 colocou a propriedade literária, científica e artística disciplinada entre os direitos de propriedade no seu artigo 524, parágrafo único. No entanto o Código Civil de 2002 suprimiu esse capítulo, pois entende que é um ramo autônomo porque essas modalidades apresentam naturezas diversas que impede uma única classificação (VENOSA, 2007, p. 155).

Segundo Hammes (2002, p. 18), o direito de autor, mesmo sendo um direito de propriedade, foi classicamente tratado no direito das coisas, o que o desnaturou, levaram muitos a compreendê-lo mal e colocá-lo em um segundo plano. Nessa mesma linha, Diniz (2008, p. 119120) reconhece os bens incorpóreos como objeto de propriedade, pois em face do ordenamento jurídico a propriedade imaterial é regulada como uma relação de domínio do mesmo teor de um bem corpóreo. Ainda, segundo a autora, a Constituição Federal situa a propriedade imaterial no mesmo plano da propriedade sobre coisas corpóreas, estabelecendo no artigo $5^{\circ}$, XXIX, que a lei assegurará aos autores de inventos industriais privilégios temporários para a utilização, bem como proteção às criações industriais, à propriedade das marcas, aos nomes de empresas e a outros signos distintivos, tendo em vista o interesse social e o desenvolvimento tecnológico e econômico do país. Sendo assim as coisas tanto corpóreas como as incorpóreas podem ser objetos do domínio desde que apropriáveis pelo homem.

$\mathrm{Na}$ atualidade o direito autoral encontra-se tão presente na sociedade que é difícil parar para refletir seus efeitos no cotidiano. A obra intelectual é de suma importância, pois traz um 
ISSN 1981-3694

(DOI): $10.5902 / 1981369410564$

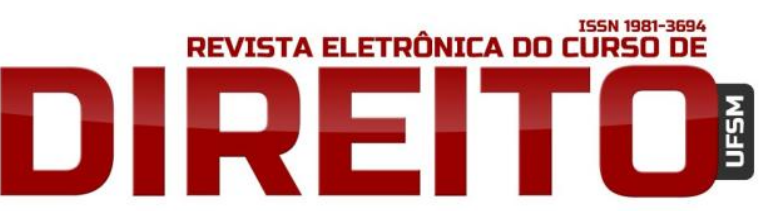

A FUNÇÃO SOCIAL DO DIREITO AUTORAL E O ACESSO AO CONHECIMENTO

Alexandre Azis Pereira Filho, Oseias Amaral, Naila Fernanda SbsczK PEREIRA MENEGUETTI

vasto conhecimento, informação e cultura para sociedade. A utilização dos bens de propriedade intelectual vem representando cada vez números mais significativos dentro da economia globalizada (BORGES, 2004, p. 32). 0 direito do autor é subdivido em dois, direitos patrimoniais e direitos morais, o primeiro consiste em um caráter puramente econômico e o segundo consiste no direito do autor de defender sua obra. Sendo assim abordaremos os direitos patrimoniais de direito de autor, a partir de uma análise da Constituição Federal do art. $5^{\circ}$ incisos XXVII e XXVIII.

De acordo com Souza (2005, p. 7), são assegurados constitucionalmente ao autor os seguintes direitos patrimoniais: a) 0 autor é o titular dos direitos sobre as obras autorais que criar, em caráter de exclusividade; b) Este direito se aplica tanto às obras puramente individuais como as que estiverem inseridas em uma obra coletiva; c) A projeção da personalidade é protegida, mesmo quando tratar-se da utilização patrimonial da obra; d) Estes direitos são transmissíveis aos herdeiros, portanto objeto de sucessão hereditária; e) 0 tempo post-mortem destes direitos será limitado; f) É assegurado aos autores o direito de fiscalizar o aproveitamento econômico da obra; g) A legitimidade ativa para a fiscalização dos usos ou proveitos é extensiva às associações e sindicatos.

Simplificando de forma genérica, a obra pertence ao autor, consequentemente tem todos os direitos decorrentes de um direito de propriedade. Pode utilizá-la com exclusividade, pode permitir ou não permitir que outros utilizem. A sua vontade determina o que acontece com a obra. Sendo que qualquer utilização depende de sua autorização (HAMMES, 2002, p. 81).

Ao contrário dos direitos patrimoniais, que regulam o exercício do poder econômico do autor sobre a utilização de sua obra por terceiros. Os direitos morais visivelmente procuram defender a relação do autor com a própria obra. Nesse sentido Paranaguá e Branco (2009, p. 47), descrevem que os direitos morais do autor são indicados pela Lei dos Direitos Autorais no seu art.24 que são: a) 0 de reivindicar, a qualquer tempo, a autoria da obra; b) 0 de ter seu nome, pseudônimo ou sinal convencional indicado ou anunciado, como sendo o do autor, na utilização de sua obra; c) 0 de conservar a obra inédita; d) 0 de assegurar a integridade da obra, opondose a quaisquer modificações ou à prática de atos que, de qualquer forma, possam prejudicá-lo ou atingi-lo, como autor, em sua reputação ou honra; e) 0 de modificar a obra, antes ou depois de utilizada; f) 0 de retirar de circulação a obra ou de suspender qualquer forma de utilização já autorizada, quando a circulação ou utilização implicarem afronta à sua reputação e imagem; g) 0 de ter acesso a exemplar único e raro da obra, quando se encontre legitimamente em poder de outrem para o fim de, por meio de processo fotográfico ou assemelhado, ou audiovisual, 
preservar sua memória, de forma que cause o menor inconveniente possível a seu detentor, que, em todo caso, será indenizado de qualquer dano ou prejuízo que lhe seja causado.

Carboni (2008, p. 62-63) afirma que os direitos morais de autor, assim com os demais direitos da personalidade, têm com fundamento o princípio geral da pessoa humana, consagrada na Constituição Brasileira. Analisando o direito autoral, sobretudo com relação aos direitos patrimoniais, vislumbra-se uma visão antiga vinculada a um caráter exclusivista como outrora ocorria com o direito de propriedade, a doutrina se bate por critérios que tornem o uso um tanto mais aberto, voltado para um lado social, e não somente como ocorre agora com intuito apenas de auferir lucros sobre sua obra. Desta maneira conforme ilustrado acima, o direito de autor é um ramo da propriedade intelectual, que lida com as coisas intangíveis, oriundas das inovações e criações da mente humana, logo também é direito de propriedade (BRASIL, 2010, p. 4).

\subsection{A lei 9.610/98 como instrumento de proteção do autor}

A regulação dos direitos autorais no Brasil, atualmente é feita por meio da Lei 9.610 de 1998, que veio a substituir a Lei $n^{\circ} 5.988$ de 1973. Esta legislação tem como objeto a proteção dos bens intelectuais de cunho literário, científico ou artístico (PIRES; TOLOTTI, 2005, p. 4). A Lei 9.610/98 no seu artigo 11 (BRASIL, 1998) descreve quem pode ser autor, ou seja, o autor é a pessoa física criadora de obra literária, artística ou científica.

A proteção dos direitos autorais não depende do registro da obra é o que descreve o art. 18 da LDA, portanto, o direito do autor nasce com a própria criação autoral e não necessita de qualquer outro formalismo. Segundo Kischelewski (2012, p. 5), embora no Brasil, ainda exista, em determinadas áreas, a cultura de “quem não registra, não é dono”. Na prática, porém, isso não ocorre mais, pois a legislação dos direitos autorais aboliu essa conduta, o autor não precisa gastar qualquer quantia com registros públicos para se proteger.

O artigo 8 da Lei 9.610/98 elenca os objetos que não são protegidos: a) As ideias, procedimentos normativos, sistemas, métodos, projetos ou conceitos matemáticos como tais; b) Os esquemas, planos ou regras para realizar atos mentais, jogos ou negócios; c) Os formulários em branco para serem preenchidos por qualquer tipo de informação, científica ou não, e suas instruções; d) Os textos de tratados ou convenções, leis, decretos, regulamentos, decisões judiciais e demais atos oficiais; e) As informações de uso comum, tais como calendários, 
agendas, cadastros ou legendas; f) Os nomes e títulos isolados; g) 0 aproveitamento industrial ou comercial das ideias contidas em obras.

Paranaguá e Branco (2009, p. 31) destacam que objetos de que trata o artigo $8^{\circ}$ da Lei dos Direitos Autorais não são protegidos, pois as ideias são de uso comum e, por isso, não podem ser aprisionadas pelo titular dos direitos autorais. Por sua vez, o art. 7 da Lei 9.610/98 disponibiliza quais são as obras protegidas:

I - os textos de obras literárias, artísticas ou científicas;

II - as conferências, alocuções, sermões e outras obras da mesma natureza;

III - as obras dramáticas e dramático-musicais;

IV - as obras coreográficas e pantomímicas, cuja execução cênica se fixe por escrito ou por outra qualquer forma;

$\mathrm{V}$ - as composições musicais que tenham ou não letra;

$\mathrm{VI}$ - as obras audiovisuais, sonorizadas ou não, inclusive as cinematográficas;

VII - as obras fotográficas e as produzidas por qualquer processo análogo ao da fotografia;

VIII - as obras de desenho, pintura, gravura, escultura, litografia e arte cinética;

IX - as ilustrações, cartas geográficas e outras obras da mesma natureza;

$X$ - os projetos, esboços e obras plásticas concernentes à geografia, engenharia, topografia, arquitetura, paisagismo, cenografia e ciência;

$\mathrm{XI}$ - as adaptações, traduções e outras transformações de obras originais, apresentadas como criação intelectual nova;

XII - os programas de computador;

XIII - as coletâneas ou compilações, antologias, enciclopédias, dicionários, bases de dados e outras obras, que, por sua seleção, organização ou disposição de seu conteúdo, constituam uma criação intelectual.

É relevante mencionar que só são protegidas as obras que tenham sido exteriorizadas. Sendo assim, as ideias não são passíveis de proteção por direitos autorais. No entanto, o meio em que a obra é expressa tem pouca ou nenhuma importância, exceto para produzir prova de sua criação ou de sua anterioridade, já que não se exige a exteriorização da obra em determinado meio específico para que, a partir daí, passe a existir o direito autoral (PARANAGUÁ; BRANCO, 2009, p. 24-25). Além da proteção do direito de autor por meio da Lei 9610/98 a violação dos direitos autorais por meio de plágio é crime de acordo com o artigo 184 do Código Penal brasileiro. A pena pode consistir em detenção de 3 meses a 1 ano e multa. Caso o plágio seja cometido com intenção de se obter lucro, seja de forma direta ou indireta, a pena será ainda maior, variando de 2 a 4 anos, além do pagamento de multa (KISCHELEWSKI, 2012, p. 7). Contudo, os componentes da proteção jurídica são os aspectos de natureza patrimonial e pessoal. Dentre estes últimos, também chamados de direitos morais, incluem-se as seguintes prerrogativas: identificação e crédito, modificação e preservação da obra, retirada. Já os direitos patrimoniais encerram todas as formas de aproveitamento econômico da obra pelo titular. Essas possibilidades são ilimitadas e incluem essencialmente os direitos de reprodução e 
a representação da obra (SOUZA, 2005, p. 2). Fica claro, portanto, que o sistema de proteção dos direitos autorais se baseia na tutela do autor, permitindo a utilização de sua obra apenas mediante expressa autorização legal ou com seu consentimento.

\section{O ACESSO À EDUCAÇÃO, À CULTURA, À INFORMAÇÃO E AO CONHECIMENTO}

De acordo com o artigo XXVII da Declaração Universal dos Direitos do Homem, "todo homem tem o direito de participar livremente da vida cultural da comunidade, de fruir as artes e de participar do progresso científico e de seus benefícios” (CARBONI, 2008, p. 101).

Os direitos constitucionais de acesso à informação, à cultura e a educação, estão previstos nos artigos $5^{\circ}$, inciso XIV, 215 e 205 da Constituição Federal. Quanto à importância desses direitos, como afirma Branco (2007, p. 122), citando Emilio Garcia Mendes, na atual etapa do desenvolvimento tecnológico, em que o acesso ao conhecimento constitui variável decisiva e fundamental de uma existência humana digna, o direito à educação não pode ser submetido a qualquer tipo de negociação, devendo ser entendido como prioridade tão absoluta quanto à abolição da escravidão ou da tortura.

A Constituição Federal consagrou a educação como direito fundamental, tendo por objetivo criar condições para que as pessoas se desenvolvam e vivam em sociedade. Assim, o acesso à educação é garantido na Carta Magna, representa o principal veículo pelo qual aqueles que são social e economicamente desfavorecidos posam modificar essa condição e participar integralmente da comunidade a qual está inserido (MOTTA; RAMPAZZO, 2009).

$O$ direito de acesso à informação, à cultura e ao conhecimento é um direito consubstanciado no princípio da universalidade, ou seja, é um direito pertencente e garantido a todos. É, portanto, um direito social; cuja finalidade precípua é proporcionar a efetividade da melhoria de condições de viver, ou seja, existência digna possibilitada aos hipossuficientes. Enquanto direito fundamental social, faz-se necessário para a preservação da dignidade da pessoa humana, proporcionando um mínimo existencial, fundamento do Estado Democrático de Direito (ZANETTI; GOMES; CLARK, 2008, p. 4). Hodiernamente há uma evolução constante e veloz dos meios tecnológicos e esses novos meios tecnológicos ocasionaram uma revolução nos meios comunicativos e de acesso às fontes de conhecimento e cultura, o que consequentemente, provocou o surgimento de um novo modelo de sociedade. Desta maneira, tornam-se 
ISSN 1981-3694

(DOI): $10.5902 / 1981369410564$

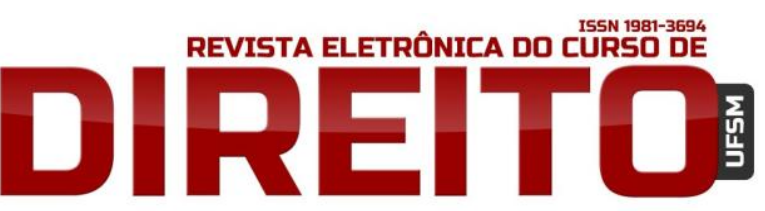

A FUNÇÃO SOCIAL DO DIREITO AUTORAL E O ACESSO AO CONHECIMENTO

Alexandre Azis Pereira Filho, Oseias Amaral, Naila Fernanda SbsczK PEREIRA MENEGUETTI

extremamente valiosas as ferramentas que a internet e as demais inovações tecnológicas proporcionam para o compartilhamento dos bens intelectuais, já que estes se constituem como fontes de conhecimento e o acesso a eles é requisito para a promoção do desenvolvimento cultural, econômico e tecnológico de uma sociedade (PIRES; REIS, 2010, p. 28-29).

Com o advento de novos meios tecnológicos, a exemplo da internet diminuíram, de forma fantástica, as barreiras de espaços e tempo, promovendo o desenvolvimento da sociedade informacional que tem seu fundamento baseado no conhecimento, na pesquisa, na fácil acessibilidade e utilização da informação (WACHOWICZ, 2008, p. 7). Nesse sentido nota-se um conflito de direitos fundamentais visualizados na divergência de interesses individuais do autor com interesses coletivos da sociedade, especialmente um conflito do direito à propriedade e à personalidade do autor versus o direito à informação, à cultura e à educação da sociedade (PIRES; REIS, 2010, p. 34). Assim o direito de acesso à informação e à cultura é, sem dúvida, o que possui uma maior possibilidade de conflito com o direito de autor, principalmente na sociedade da informação, que tem a internet como um dos principais instrumentos de divulgação do conhecimento e do saber (CARBONI, 2008, p. 200).

No decorrer do século XX, o desenvolvimento das tecnologias foi gradativamente diminuindo a distância entre o homem, a obra cultural e a propriedade intelectual. 0 ápice foi o advento da internet, em meados dos anos 90. O acesso a obras do mundo inteiro facilita enormemente as possibilidades de disseminação de conhecimento e de matéria prima para a educação e, pelo menos, ajuda também a construir uma comunidade global (BRANCO, 2007, p. 120). Desta forma os países em desenvolvimento como o Brasil, têm a necessidade de um amplo acesso ao conhecimento à cultura e à informação, de forma a diminuir a distância cultural e tecnológica com os países desenvolvidos (CARBONI, 2005, p.2). Para que essa distância diminua se faz necessária a criação de obras intelectuais, pois as mesmas são fonte de conhecimento, cultura e informação, no entanto o custo de produção de um livro pode ser compreendido pela conjunção de dois componentes. O primeiro é o custo de criação do trabalho, naturalmente, esse valor não decorre do número de exemplares editados ou vendidos, já que diz respeito ao tempo gasto pelo autor para escrever o livro mais os gastos do editor com o preparo da edição. O segundo componente, o custo de produção dos exemplares que se pretende editar, incluídos os custos de impressão, encadernação e distribuição (BRANCO, 2007, p. 127).

Hodiernamente, frente à importância que o conhecimento e até mesmo a informação representam para a sociedade, não há como se admitir a análise de um direito de autor com uma visão unitária, em que ao criador da obra intelectual é outorgada exclusividade absoluta 
sobre a obra. De outro lado, não há como negar ao autor a tutela sobre o bem de sua criação; entretanto, essa proteção deve estar em harmonia com os direitos da sociedade, e isto, em outras palavras, significa dizer que da mesma forma que ocorre com a propriedade material, o direito de autor também deve cumprir sua função social (PIRES; TOLOTTI, 2005, p. 6).

Carboni (2005, p. 13) defende a tese de que o Estado poderia interferir nas obras protegidas pelo direito autoral, até na forma de desapropriação, visando ao cumprimento do seu dever de zelar pela proteção do patrimônio cultural brasileiro. Em seu entendimento, tal interferência deveria ter como fundamento e limite a proteção do patrimônio da cultura nacional e, consequentemente, os excessos não seriam permitidos, pois aí sim haveria violação de direitos autorais. Desta maneira se faz necessário uma reforma na Lei dos direitos autorais, pois a mesma traz as limitações do direito de autor em um rol taxativo, contrariando a função social do direito autoral. Entretanto a função social do direito do autor visa um equilíbrio entres esses direitos conflitantes, para que as pessoas não sejam prejudicadas, procurando uma forma de desenvolver seus conhecimentos, conquistando novos horizontes, para viver uma vida digna.

\subsection{O Conflito entre o Direito Autoral e o Acesso ao Conhecimento}

Lemos e Branco Junior (2012, p. 7) afirma que a lei brasileira de direitos autorais é tida pelos especialistas no assunto como uma das mais restritivas do mundo. Percebe-se esse fato, por exemplo, no artigo 46, inciso II, da atual Lei dos direitos autorais, que proíbe a cópia integral de obra alheia, o que consequentemente, faz com que condutas que se afiguram corriqueiras no mundo contemporâneo, especialmente, a partir da utilização da internet e demais tecnologias, sejam, a rigor, contrárias à lei. Nesse contexto surge um conflito de direitos fundamentais: de um lado o direito de autor de obter os frutos econômicos de seu trabalho e o monopólio sobre a utilização de sua obra e de outro lado, o direito da sociedade à informação, à educação e à cultura (PIRES; TOLOTTI, 2005, p. 5). Nesse sentido, as limitações traçadas pela Lei $9.610 / 98$ no seu artigo 46, inciso II, não são suficientes para resolver os conflitos entre o direito individual do autor e o interesse público à livre utilização de obras intelectuais.

A previsão numerus clausus dessas limitações contraria a função social do direito de autor (ASCENSÃO, 2002, p. 48). Seguindo essa linha de pensamento, Carboni (2012, p. 12) é favorável à regulamentação das limitações aos direitos autorais na forma de princípios gerais e não à enumeração de situações taxativas. Isso porque o princípio geral pode ser moldado pelo juiz no caso concreto, além de sobreviver mais facilmente às mudanças sociais e tecnológicas. 
Na mesma linha, Abrão (2002) afirma que seria prejudicial ao editor de determinada obra se 200 ou 300 alunos fizessem cópia integral de obra recém-publicada. Nesse caso, a autora está preocupada com o fator econômico do autor, pois acarretaria prejuízos para o autor, pois ainda afirma que os argumentos da cópia integral de exemplar de obras protegidas são consistentes. Branco (2007, p, 131) discorda da afirmação de Abrão, também sob um enfoque econômico, sustenta que é necessário considerar que o Brasil tem um percentual vergonhosamente alto de pessoas vivendo na pobreza e que não há como esperar que os estudantes de famílias pobres paguem pelas obras que vão garantir sua educação. Embora não apresentam dados, o autor assevera que, na maioria dos casos, os alunos pobres estão fora do mercado porque simplesmente não têm dinheiro para obter os bens materiais de que precisam para sua formação. Dessa forma, nenhum prejuízo, está sendo imputado ao editor, pois se não fosse pela possibilidade de cópia, os alunos não teriam acesso a esses bens de qualquer outra forma.

Quanto ao direito de reprodução, conforme o artigo acima citado, a Lei 9.610/98 não especificou exatamente o que representa “pequenos trechos" de uma obra, restando muitas dúvidas e discussões no meio acadêmico e jurídico. Cumpre salientar que as limitações e exceções ao direito de autor contidas na Lei 9.610/98 são fundamentadas no interesse social, todavia este rol de limitações da forma em que se encontra, vem a contrariar o princípio da função social de direito de autor, por se tratar de um rol taxativo, que prevê hipóteses fechadas e que não são suficientes para atender às necessidades da sociedade ao acesso às obras intelectuais. A doutrina busca criar fundamentos jurídicos para superar esta limitação. Pires e Tolotti (2005, p.14), afirmam que a cópia sem intuito de obtenção de lucro, para uso particular e principalmente quando servir para uso acadêmico não pode ser considerado como um ato ilícito. Não se pode permitir, à luz da função social do direito de autor, que se restrinja o acesso à informação, cultura e educação, assim consideradas como bens maiores da sociedade, em função do caráter econômico do direito de autor.

Carboni (2012, p. 5-6) cita ainda o conflito entre o direito de autor e o direito de acesso à informação e à cultura que surge nos projetos de digitalização do acervo de algumas discotecas públicas, com intuito de proteger as obras musicais da deterioração dos discos. 0 intuito desses projetos é evidentemente social, isto é o de garantir o direito da população de continuar ouvindo as músicas contidas no acervo da discoteca. Todavia, a digitalização do acervo da discoteca pública não seria permitida sem expressa anuência dos titulares dos direitos autorais sobre as músicas, pois tal processo envolve uma reprodução integral da obra, o que em tese violaria a lei $9.610 / 98$, principalmente porque o artigo $4^{\circ}$ da Lei dos Direitos Autorais 
ISSN 1981-3694

(DOI): $10.5902 / 1981369410564$

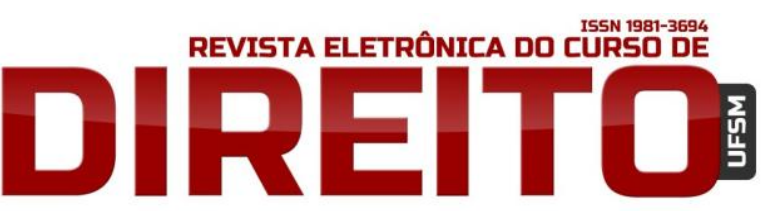

A FUNÇÃO SOCIAL DO DIREITO AUTORAL E O ACESSO AO CONHECIMENTO

Alexandre Azis Pereira Filho, Oseias Amaral, Naila Fernanda SbsczK PEREIRA MENEGUETTI

estabelece que os negócios jurídicos envolvendo direitos autorais devam ser interpretados restritivamente. Portanto do ponto de vista da função social do direito de autor, estas limitações por estarem enquadradas em um rol taxativo, em muitas ocasiões ainda servem de obstáculo aos direitos sociais de acesso à informação, educação e cultura (PIRES; TOLOTTI, 2005, p. 3). Dessa forma, é possível pensar em exercício abusivo do direito de autor, que, portanto, fere a ordem jurídica, uma vez que constitui um desvirtuamento da sua finalidade social. 0 titular de direitos autorais sobre uma obra, que, ao utilizar seu direito, vem a causar dano a outrem, contraria o espírito do próprio instituto, caracterizando ato ilícito, passível de indenização. 0 abuso do direito de autor também pode, dependendo do caso, caracterizar infração da ordem econômica ou a prática de concorrência desleal (ABRÃO, 2002, p. 218).

A pessoa física e/ou jurídica quando impõe embaraços para livre circulação da obra caracteriza exercício abusivo do direito de autor fere a ordem jurídica, pois constitui um desvirtuamento da sua finalidade social. 0 titular de direitos autorais sobre uma obra, que, ao utilizar seu direito, vem a causar dano a outrem, contraria o espírito do próprio instituto, caracterizando ato ilícito, passível de indenização. 0 abuso do direito de autor também pode, dependendo do caso, caracterizar infração da ordem econômica ou a prática de concorrência desleal (CARBONI, 2012, p. 13). Entretanto percebe-se um conflito sem proporções e de difícil solução, em que de um lado tem-se o autor, que requer a tutela sobre as suas criações, para que possa receber a remuneração pela utilização dos bens provenientes de seu intelecto, inclusive como meio de incentivo à criação; de outro lado tem-se a coletividade que pretende continuar a se beneficiar das tecnologias ora existentes para fins de acesso e difusão da informação e do conhecimento, como meio de promoção do desenvolvimento da sociedade (PIRES; REIS, 2010, p. 29). O mesmo conflito se põe com relação aos meios tecnológicos que, por um lado, contribuem com o desenvolvimento social na medida em que permitem à coletividade maior facilidade no acesso e disseminação do conhecimento e da cultura. Por outro lado, a fácil acessibilidade e compartilhamento dos bens intelectuais causa uma "crise" no direito de autor, ocasionando conflitos entre o autor e a coletividade, no que tange ao direito de retribuição pelo uso dos bens de criação contra o direito de acesso a tais obras intelectuais pela sociedade (PIRES; REIS, 2010).

Não se nega que as criações intelectuais precisam de proteção, pois, propicia ao autor retirar os proventos correspondentes da sua criação, inclusive, como meio de incentivo a produção de novas obras. Entretanto, esta proteção deve sofrer restrições sempre que servir de empecilho à difusão do conhecimento e disseminação de cultura (PIRES; TOLOTTI, 2005, p. 7). 
A Lei 9.610/98 e a Carta Magna não contêm dispositivos expressos para solucionar os possíveis conflitos entre os interesses do autor e os da coletividade relativos ao acesso à informação e à cultura. Na ausência de regulamentação adequada, na esteira de Carboni (2005, p. 15), este trabalho sustenta que deverão ser aplicadas ao caso concreto as normas relativas à função social da propriedade e de abuso de direito, conforme será analisado adiante.

\subsection{A Nova lei de Direito Autoral como Mecanismo de Acesso à Educação, à Cultura, à informação e ao Conhecimento}

A Lei $\mathrm{n}^{\circ} 5.988$ de 1973, revogada pela atual lei de direitos autorais, ao tratar das limitações dos direitos autorais autorizava em seu artigo 49, inciso II autoriza à cópia privada, desde que não representasse ofensa aos direitos do autor. No entanto é permitida a reprodução, em um só exemplar, de qualquer obra, contanto que não se destine à utilização com intuito de lucro. Desta maneira a partir da Lei 9.610/98 a cópia integral de qualquer obra tornou-se proibida, nesse caso em comento verifica-se um retrocesso na atual Lei dos direitos autorais (PIRES; TOLOTTI, 2005, p. 9).

Sob o ponto de vista do compartilhamento da informação há um retrocesso na atual Lei dos direitos autorais, pois a Lei $\mathrm{n}^{\circ} \mathbf{5 . 9 8 8 / 7 3}$ possibilitava a cópia de um só exemplar, contanto que não fosse à utilização com intuito de lucro, enquanto atual Lei dos direitos autorais só admite-se cópia de pequenos trechos, para uso exclusivo do copista sem intuito de lucro.

A Associação Brasileira da Propriedade Intelectual (ABPI, 2012), é uma associação sem fins lucrativos, é composta por pessoas físicas e jurídicas, associações de profissionais, instituições acadêmicas, instituições oficiais, entendendo que na legislação atual a regulamentação das limitações ao Direito de Autor não são satisfatórias, aprovou em 20 de outubro de 2005 a resolução de $n^{\circ}$ 67, a qual propõe a alteração do art. 46 da lei 9.610 de 1998, que passaria a vigora com o seguinte texto:

Art. 46. I - tenha como objetivo, crítica, comentário, noticiário, educação, ensino, pesquisa, produção de prova judiciária ou administrativa, uso exclusivo de deficientes visuais em sistema Braile ou outro procedimento em qualquer suporte para esses destinatários, preservação ou estudo da obra, ou ainda, para demonstração à clientela em estabelecimentos comerciais, desde que estes comercializem os suportes ou equipamentos que permitam a sua utilização, sempre na medida justificada pelo fim a atingir;

II - sua finalidade não seja essencialmente comercial para o destinatário da reprodução e para quem se vale da distribuição e da utilização das obras intelectuais; 
III - o efeito no mercado potencial da obra seja individualmente desprezível, não acarretando prejuízo à exploração normal da obra; Parágrafo Único - A aplicação da hipótese prevista no inciso II deste artigo não se justifica somente pelo fato de o destinatário da reprodução e quem se vale da distribuição e da utilização das obras intelectuais serem empresa ou órgão público, fundação, associação ou qualquer outra entidade sem fins lucrativos.

A alteração sugerida pela ABPI busca o atendimento da função social do direito de autor por meio de uma alteração da característica do rol das limitações ao direito de autor, que passaria de uma relação taxativa de limitações a um rol aberto constituído de princípios gerais, que podem ser aplicados e moldados pelo juiz de acordo com caso concreto (PIRES; TOLOTTI, 2005, p.12). Discute-se também no Congresso Nacional a alteração da Lei $9.610 / 98$, para que se estabeleça nova modalidade de limitação aos direitos de autor. Trata-se do Projeto de Lei 5046 de 2005, de autoria do Deputado Antônio Carlos Mendes Thame, que alteraria o inciso I do artigo 46, acrescentando-lhe uma alínea de letra "e", ficando, então, da seguinte forma:

Art. 46. I - a reprodução: e) de qualquer obra, em um só exemplar, para uso exclusivo do estudante universitário, sem fins comerciais.

Assim o projeto de lei mencionada busca fazer com que os interesses individuais do autor não sirvam de obstáculo ao acesso a obras por estudantes quando se trata da utilização para fins educacionais. Entretanto, não é objetivo do projeto um desrespeito generalizado aos direitos do autor, mas o que se pretende é que estes funcionem de forma integrada com os direitos à informação, cultura e educação, ou em outras palavras pode-se dizer que o intuito é de a função social do direito de autor seja cumprida (PIRES; TOLOTTI, 2005, p. 13).

0 presente projeto encontra-se arquivado nos termos do artigo 105 do regimento Interno da Câmara dos Deputados, tendo em vista a proposta do projeto de lei de alteraria o artigo 46, inciso I da Lei 9.610/98, o projeto teve uma boa proposta de alterar o artigo 46, inciso I da Lei dos direitos autorais, mas foi infeliz ao mencionar para uso exclusivo de qualquer universitário, deixando a grande massa de fora. No entanto analisando a redação do projeto de lei 5046 de 2005, fica claro que sua redação foi mal formulada, e ainda focou apenas em livros, deixando de fora os discos. Assim o direito a reproduzir uma obra em um só exemplar sem fins comerciais deveria ser para todos, e não exclusivamente para os estudantes universitários, pois o artigo $5^{\circ}$ da Constituição Federal de 1988 preleciona que todos são iguais. 


\subsection{A Função Social do Direito de Autor}

O direito de autor tem como função social a promoção do desenvolvimento econômico, cultural e tecnológico, mediante a concessão de um direito exclusivo para a utilização e exploração de determinadas obras intelectuais por certo prazo, findo o qual, a obra cai em domínio público e pode ser utilizada livremente por qualquer pessoa (CARBONI, 2008, p. 97).

Do ponto de vista do interesse público, existem diversas funções do direito de autor que justificam a sua existência, entretanto esse direito alcança sua finalidade maior, quando da destinação pública da obra, permitindo o acesso da coletividade à cultura, à educação, ao conhecimento e à informação, levanta-se assim, como patrimônio a ser protegido, pois seus efeitos determinam transformações no complexo intelectual da sociedade (PIRES; REIS, 2010).

Pires e Reis (2010, p. 36) sustentam que a atual Lei de direitos autorais encontra-se incompatível com a realidade tecnológica contemporânea e, consequentemente, com as práticas adotadas pela sociedade da informação, sendo necessário que se faça uma leitura extensiva das limitações do direito de autor dispostas no artigo 46 da Lei 9.610/98, à luz da Constituição e de todos os direitos fundamentais em jogo, a fim de se buscar a efetivação da função social do direito de autor. Esta é a posição advogada por este trabalho, ou seja, a aplicação da função social do direito de autor não deve ser entendida como um discurso atentatório aos direitos de propriedade intelectual, mas como uma contribuição para que tais direitos sejam aprimorados e seu uso abusivo coibido. Assim a função social do direito de autor visa corrigir o instituto para que se reafirme como instrumento necessário ao desenvolvimento econômico, cultural e tecnológico e não como um fim em si mesmo (CARBONI, 2012, p. 15).

A doutrina se dedica a buscar formas de conciliar o direito de autor com sua função social. Por exemplo, Pires e Reis (2010, p. 37) afirmam que se deve entender que a sociedade quando faz uso dos bens intelectuais, para uso próprio, ou mesmo para uso coletivo com fins educacionais ou culturais e sem fins lucrativos, estará dentro do âmbito do que se entende por função social do direito do autor, não podendo taxar-se, de modo algum, tais utilizações das obras como pirataria. No mesmo sentido, Hammes (1998, p. 76-77) refere que "juntamente com a aceitação do direito de autor, desenvolveu-se o reconhecimento de que o mesmo está sujeito igualmente a uma vinculação social. Em nome do interesse comum, o autor deve tolerar restrições aos seus direitos”. Para Branco (2007, p. 128) com o conceito contemporâneo de funcionalização dos institutos jurídicos, o direito autoral deve estar a serviço do cumprimento de sua função social, o que abrange a garantia de acesso ao conhecimento e à educação. 
A aplicação do princípio da função social da propriedade aos direitos autorais pressupõe o resgate da idéia de que os direitos autorais constituem um ramo do direito de propriedade intelectual, e esta compõe um ramo do direito de propriedade. Tal enquadramento não está previsto expressamente na Constituição, todavia, é construção doutrinária que busca conciliar a aplicação do princípio da função social da propriedade para este ramo do Direito (MAGRANI, 2007, p 10). Assim, a conjugação do direito de autoral e do princípio da função social tem como objetivo permitir à sociedade o acesso ao conhecimento, à educação, à cultura e a informação, sem restringir os direitos autorais consagrados pela Carta Magna.

\section{CONCLUSÃO}

A evolução histórica, demonstrou que desde os primeiros momentos, na sociedade romana o direito de propriedade apresentava um caráter individualista, todavia no decorrer dos séculos o direito de propriedade foi se modelando para um contexto social, sofrendo inúmeras mudanças até chegar à compreensão atual, ou seja, de que a propriedade está vinculada ao princípio da função social.

Evidenciou-se que o direito do autor restringe o acesso ao conhecimento, todavia, tal conflito pode ser resolvido mediante a aplicação do princípio da função social ao direito autoral.

Por fim o direito ao acesso à educação, à cultura, à informação e ao conhecimento para a sociedade, são garantidos pela Constituição Federal de 1988 nos artigos $5^{\circ}$ XIV, 6, 205 e 215, porém sem desrespeitar o lado o direito de autor, na forma regulada pela Lei 9.610/98.

Constatou-se que este conflito é de difícil solução, mas o princípio da função social da propriedade pode servir como instrumento jurídico teórico útil para mediar o conflito.

\section{REFERÊNCIAS}

ABPI. Associação Brasileira da Propriedade Intelectual. Resolução número 67 de 20 de outubro de 2005. Disponível em: <http: / /www.abpi.org. br/biblioteca1.asp?idioma=\&secao=Biblioteca\&s ubsecao=Resolu\%E7\%F5es\%20da\%20ABPI\&assunto=Resolu\%E7\%E30\%20espec\%EDfica\&tid=2>. Acesso em 22 maio 2012.

ABRÃO, Eliane Yachouh. Direitos de autor e direitos conexos. São Paulo: Do Brasil, 2002. 
ASCENSÃO, José de Oliveira. Direito intelectual, exclusivo e liberdade. In: Revista da ABPIAssociação Brasileira da Propriedade Intelectual. $n^{\circ}$ 59, jul./ago.2002.

BELTRÃO, I. Função Social da Propriedade, Evolução Histórica-Constitucional e Politíca Urbana. Disponível em: <http://portalciclo.com.br/downloads/artigos/direito/funcao_social _da_propriedade_evolucao_historica_constitucional_e_politica_urbana.pdf $>$. Acesso em 10 maio 2012.

BITTAR, Carlos Alberto. Direito de Autor. 3. ed. Rio de Janeiro: Forense Universitária, 2001.

BONAVIDES, Paulo. Curso de Direito Constitucional. 4a Ed. São Paulo: Malheiros Editores, 1993.

BORGES, R. Caderno Eu \& Fim de Semana, Valor Econômico, Rio de Janeiro, 16 jul.2004.

BRANCO, B. A Lei Autoral Brasileira como elemento de restrição à Eficácia do Direito Humano à Educação. Revista Internacional de Direitos Humanos, v. 4, n. 6, p. 121-141, 2007.

BRASIL. Câmara dos Deputados. Projeto de Lei n. 5046/2005. Ementa: [Altera a Lei n 9610 , de 19 de fevereiro de 1998, que "Altera, atualiza e consolida a legislação sobre direitos autorais e dá outras providências"]. Disponível em:<http://www.camara.gov.br/sileg/integras/ 295013.pdf>. Acesso em 03 maio.2012.

BRASIL. Ministério da Cultura - Secretaria de Políticas Culturais: Coordenação Geral de Direito Autoral. Fórum Nacional de Direito Autoral, 2010.

BRASIL. Constituição (1824). Constituição Política do Império do Brazil. Disponível em:<http: // www.planalto.gov.br/ccivil_03/Constituicao/Constituicao24.htm>. Acesso em 26 mar.2012.

BRASIL. Constituição (1891). Constituição da República dos Estados Unidos do Brasil. Disponível em: <http://www.planalto.gov.br/ccivil_03/Constituicao/Constituicao91.htm>. Acesso em 26 mar.2012.

BRASIL. Constituição (1934). Constituição da República dos Estados Unidos do Brasil. Disponível em: <http://www.planalto.gov.br/ccivil_03/Constituicao/Constituicao34.htm>. Acesso em 26 mar.2012.

BRASIL. Decreto Lei $n^{\circ} 3.071$, de $1^{\circ}$ de Janeiro de 1916. Código Civil de 1916. Disponível em: <http://www.planalto.gov.br/ccivil_03/Constituicao/Constitui\%C3\%A7ao.htm>. Acesso em 26 mar.2012.

BRASIL. Constituição (1937). Constituição dos Estados Unidos do Brasil. Disponível em: <http:// www.planalto.gov.br/ccivil_03/Constituicao/Constitui\%C3\%A7ao37.htm>. Acesso em 26 mar.2012.

BRASIL. Constituição (1946). Constituição dos Estados Unidos do Brasil. Disponível em: <http: / /www.planalto.gov.br/ccivil_03/Constituicao/Constituicao46.htm>. Acesso em 26 mar.2012.

BRASIL. Constituição (1967). Constituição da República Federativa do Brasil. Disponível em: <http://www.planalto.gov.br/ccivil_03/Constituicao/Constituica067.htm>. Acesso em 26 mar.2012. 
BRASIL. Emenda Constitucional $\mathrm{n}^{\circ} 1$ de 1969. Disponível em: <http://www.planalto.gov.br/ ccivil_03/constituicao/emendas/emc_anterior1988/emc01-69.htm>. Acesso em 26 mar.2012.

BRASIL. Constituição (1988). Constituição da República Federativa do Brasil. Disponível em: <http://www.planalto.gov.br/ccivil_03/Constituicao/Constitui\%C3\%A7ao.htm>. Acesso em 26 mar.2012.

BRASIL. Decreto Lei $\mathrm{n}^{\circ}$ 9.610/98, de 19 de Fevereiro de 1998. Disponível em: <http://www. planalto.gov.br/ccivil_03/leis/L9610.htm>. Acesso em 30 abr.2012.

CARBNONI, G. Função Social do direito de Autor. Curitiba: Juruá, 2008.

CARBONI, G. Aspectos Gerais da Teoria da Função Social do Direito de Autor. Disponível em: < http://www.gcarboni.com.br/pdf/G6.pdf>. Acesso em 28 abr.2012.

CARBONI, G. Conflitos entre Direito de Autor e Direito de Acesso ao Conhecimento, à Cultura e à Informação. Mesa Temática do XXVIII Congresso Brasileiro de Ciências da Comunicação, Intercom, 2005.

COMITÊ. Direito Humanos. Disponível em: <http://www.comitepaz.org.br/download/Declara\%C 3\%A7\%C3\%A30\%20Universal\%20dos\%20Direitos\%20Humanos.pdf>. Acesso em 26 mar.2012.

DINIZ, M. H. Curso de Direito Civil Brasileiro: responsabilidade civil. 21.ed. São Paulo: Saraiva, v. 7. 2007.

Diniz, M. H. Código Civil anotado. 13. ed. São Paulo: Saraiva, 2008.

FILHO, R.N.A. A Função Social da Propriedade na Constituição Federal de 1988. Disponível em: <http://www.juspodivm.com.br/novo/arquivos/artigos/agrario/roberio-a_funcao_social .pdf>. Acesso em 04 maio 2012.

GONÇALVES, Carlos Roberto, Direitos das Coisas, 8. ed. rev. São Paulo: Saraiva, 2007.

GUERREIROS JUNIOR, Nehemias. 0 direito autoral no show bussiness: tudo o que você precisa saber. 3. ed. Rio de Janeiro: Gryphus, 2005.

HAMMES, Bruno Jorge. 0 direito de propriedade intelectual: subsídios para o ensino. São Leopoldo: Unisinos, 1998.

HAMMES, B.J. O direito de propriedade Intelectual. 3. ed. Unisinos, 2002.

LEITE, Eduardo Lycurgo. A história do direito de autor no Ocidente e os tipos móveis de Gutenberg. Revista de Direito Autoral, São Paulo, v. 1, n. 2, fev. 2005.

LEMOS, R; BRANCO JUNIOR, S.V. A Nova Feição dos Direitos Autorais e as Obras Colaborativas. Disponível em: <http://virtualbib.fgv.br/dspace/handle/10438/2796?show=full> Acesso em: 29 abr.2012.

KISCHELEWSKI, F.L.N. Entenda o Direito Autoral. Disponível em: <http: / www.aprendebrasil .com.br/pesquisa/swf/DireitoAutoral.pdf>. Acesso em 01 maio 2012. 
MAGRANI, B. Função Social do Direito de Autor: Análise Crítica e Alternativas Conciliatórias. Programa Cultura e Pensamento: Ministério da Cultura, 2007.

MATHIAS, Maria Ligia Coelho, Direito Civil: direitos reais, 1. ed. São Paulo: Atlas, 2007.

MENDES, Gilmar Ferreira et al. Curso de Direito Constitucional. 2. ed. São Paulo: Saraiva, 2008.

MOTTA, Maria Clara de Mello. Conceito Constitucional de Propriedade Tradição ou Mudança? (estudo comparado das constituições de 1824, 1946 e 1988). Rio de Janeiro: Lumen Juris, 1997.

MOTTA, I.D; RAMPAZZO, A.M.R. Conflito entre a Expansão e Efetivação do Direito À Educação e o Direito Autoral: Biblioteca Digital. Anais do XVIII Congresso Nacional do Conpedi. São Paulo, 2009.

MPF. Direitos do Homem e do Cidadão. Disponível em: <http://pfdc.pgr.mpf.gov.br/atuacao-econteudos-de-apoio/legislacao/direitos-humanos/declar_dir_homem_cidadao.pdf.m>. Acesso em 26 mar.2012.

PARANAGUÁ, P; BRANCO, S. Direitos Autorais. Direito Rio FGV, 2009.

PEREIRA. Caio Mário da Silva, Instituições de Direito Civil. 18. ed. Rio de Janeiro: Forense, 2004.

PIRES, E; REIS, J.R. A utilização das Obras intelectuais Autorais Frente às novas Tecnologias: Função Social ou Pirataria?. Revista do Direito Unisc, Santa Cruz do Sul, v. 34, p. 27-40, 2010. PIRES, E; TOLOTTI, S.M. A Função Social do Direito de Autor e a Cópia Privada. Conselho Nacional de Pesquisa e Pós-Graduação em Direito. Anais do IV Congresso Brasileiro de Ensino do Direito. Salvador, 2005.

REIS, J. R. O Direito de Autor no Constitucionalismo Contemporâneo: considerações acerca de sua função social. In: Luiz Gonzaga Silva Adolfo; Rodrigo Moraes. (Org.). Propriedade Intelectual em Perspectiva. 1. ed. Rio de Janeiro: Lumen Juris, v. 1. 2008.

SOUZA, A.R. Os Limites dos Direitos Autorais: Uma Interpretação Civil Constitucional. Conselho Nacional de Pesquisa e Pós- Graduação em Direito. Anais do IV Congresso Brasileiro de Ensino do Direito. Salvador, 2005.

USP. Magna Carta. Disponível em: <http://www.direitoshumanos.usp.br/index.php/Documentos -anteriores-\%C3\%A0-cria\%C3\%A7\%C3\%A3o-da-Sociedade-das-Na\%C3\%A7\%C3\%B5es-at\%C3\%A91919/ magna-carta-1215-magna-charta-libertatum.html>. Acesso em 26 mar.2012.

VARELLA, Marcelo Dias. Propriedade intelectual de setores emergentes: biotecnologia, fármacos e informática: de acordo com a Lei n 9.279, de 14-05-1996. São Paulo: Atlas, 1996.

VENOSA, Sílvio de Salvo. Direito Civil: direitos reais. 7. ed. São Paulo: Atlas, 2007. 
ISSN 1981-3694

(DOI): $10.5902 / 1981369410564$

REVISTA ELETRÔNICA DO CURSO DE

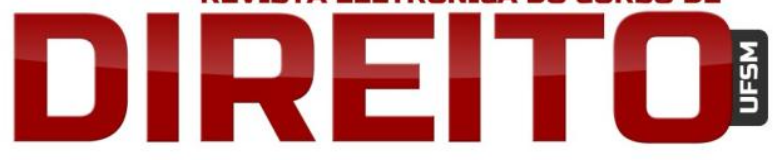

A FUNÇÃO SOCIAL DO DIREITO AUTORAL E O ACESSO AO CONHECIMENTO

Alexandre Azis Pereira Filho, Oseias Amaral, Naila Fernanda SbsczK PEREIRA MENEGUETTI

ZANETTI, C.B; GOMES, F e CLARK, G. Propriedade do Conhecimento: Desenvolvimento Econômico, Existência Digna e Justiça Social Através do Direito de Acesso À Informação. Anais do XVII Congresso Nacional do Conpedi. Brasília, 2008.

WACHOWICZ, M. Direito fundamental do autor: tensão constitucional entre a propriedade intelectual e o direito à liberdade de informação dos bens informáticos. Anais do V Seminário Internacional de Demandas sociais e Políticas Públicas na Sociedade Contemporânea. Santa Cruz do Sul: Unisc, 2008.

Recebido em: 30.08.2013

Correções em: 29.12.2013

Aprovado em: 08.03.2014 